\title{
Adolesan Çocuklarda Nutrisyonel Anemi Nedenleri
}

\section{Causes of Nutritional Anemia in Adolescent Children}

\author{
${ }^{1}$ Eren GÜZELOĞLU \\ ${ }^{1}$ TC Sağlık Bakanlığı Sancaktepe Şehit Prof Dr İlhan Varank Eğitim Araştırma Hastanesi Çocuk Sağlığı Ve Hastalıkları Klinği, İstanbul, \\ Türkiye
}

Eren Güzeloğlu: https://orcid.org/0000-0003-4316-2491

ÖZ

Amaç: Anemi çocukluk döneminde en sik 6 ay-2 yaş ile adolesan dönemde görülmektedir. Adolesan yaş grubunda anemi en sık hızlı büyüme ve diyet ile yetersiz alım nedeni ile gelişmekte olup, beslenme ile ilişkili anemi toplumumuzda sık görülmektedir. Çalışmamızda adolesan yaş grubunda nutrisyonel aneminin nedenlerini saptamay amaçladık.

Materyal ve Metot: Dokuz Eylül Üniversitesi Pediatri Anabilim Dalı'nda 01.01.2014-01.07.2015 tarihleri arasında, nutrisyonel anemi tanısı alan 90 çocuk çalışmaya dâhil edildi. Olgular 10-18 yaş aralığındaydı. Tüm olguların hastane arşiv dosyaları taranarak yaş, cinsiyet, boy, ağırlık, boya göre ağırlık (W/H) ölçümleri hasta veri kayıt formlarına kaydedildi. Ayrıca tanı sonrası olgulara eğitim durumu, anne ve babalarının eğitim durumu, semptomları ve muayene bulguları, kırmızı et, tavuk, balık, meyve, kuru baklagil, yumurta, yeşil yapraklı sebze gibi besinleri tüketim sıklığını içeren bir anket doldurtuldu.

Bulgular: Veriler uygun istatistik testler kullanılarak değerlendirildi. Çalışmaya 10-18 yaşları arasında 90 olgu dâhil edildi. 87 olguda demir eksikliği anemisi saptandı. 3 olguda $\mathrm{B}_{12}$ eksikliği anemisi saptandı. Hastaların yeterli miktarda demirden zengin yiyecek almadığı görüldü. Özellikle kırmızı et tüketiminde \%91'inin yetersiz olduğu tespit edildi.

Sonuç: Adolesanların izlemde mutlaka nutrisyonel anemi riski açısından değerlendirilmesi gerektiği ve koruyucu hekimlik uygulamalarına da yer verilmesi gerektiği düşünülmüştür.

Anahtar kelimeler: Adolesan, anemi, $\mathrm{B}_{12}$ vitamin eksikliği, demir eksikliği anemisi, folat eksikliği

\section{ABSTRACT}

Objective: Anemia is most commonly seen in 6 months to 2 years of age and adolescence in childhood. Anemia is developing mostly because of rapid growth and inadequate dietary intake in adolescent age group, nutrition-related anemia is common in our society. In this study, we aimed to determine the causes of nutritional anemia in adolescent age group.

Materials and Methods: 90 children with diagnosed nutritional anemia were included to the study at Dokuz Eylul University Department of pediatrics between 01.01.2014 - 01.07.2015. Cases were between 10 and 18 years of age. Hospital archive files of all cases were scanned and measurements of gender, height, weight, weight for height $(\mathrm{W} / \mathrm{H})$ were recorded to patient data registration form. In addition, a questionnaire containing educational status, education level of parents, symptoms and physical examination, red meat, poultry, fish, fruits, legumes, eggs, green leafy vegetables consumption frequency was filled out by cases after diagnosis.

Results: Results were analyzed by using appropriate statistical tests. 90 patients between $10-18$ years of age were included in the study. Iron deficiency anemia was found in 87 cases. $B_{12}$ deficiency anemia was detected in 3 cases. It was observed that patients didn't get enough iron rich foods. Particularly in red meat consumption was found that $91 \%$ received inadequate.

Conclusion: In the follow-up, adolescents should be evaluated in terms of nutritional anemia risk absolutely and preventive medicine should be given.

Keywords: Adolescent, anemia, folate deficiency, iron deficiency anemia, vitamin $B_{12}$ deficiency

\footnotetext{
Sorumlu Yazar / Corresponding Author:

Eren GÜZELOĞLU

Yayın Bilgisi / Article Info:

Gönderi Tarihi/ Received:20/01/2019

TC Sağlık Bakanlığı Şehit Prof. Dr. İlhan Varank Eğitim Araştırma Kabul Tarihi/ Accepted: 10/08/2019

Hastanesi Çocuk Sağlığı Ve Hastalıkları Klinği, İstanbul, Türkiye. ～Online Yayın Tarihi/ Published: 31/03/2020

Telefon: 02166063300

E-mail: dr.erenguzeloglu@gmail.com
}

Atıf/ Cited: Güzeloğlu E. Adolesan Çocuklarda Nutrisyonel Anemi Nedenleri. Online Türk Sağllk Bilimleri Dergisi 2020;5(1):25-32. doi: 10.26453/otjhs. 515125

\section{GİRIS}

Anemi; hemoglobin, hematokrit veya eritrosit değerinin yaşa ve cinse göre normal ortalama değerlerinin -2 standart derivasyonun altında olması olarak tanımlanır. ${ }^{1}$ Çocukluk döneminde, 6 ay-2 yaş ile adolesan dönemde en sık görülür. ${ }^{2}$ Dünya Sağlık Örgütü verilerine göre anemi özellikle gebelerde ve çocuklarda mortalite ve morbidite artışına yol açan yaygın bir halk sağlığı sorunudur. ${ }^{3}$ 
En s1k saptanan anemi besinsel anemidir. Besinsel anemi, bir veya birkaç besinin eksikliği ile kanda hemoglobin konsantrasyonunun anormal derecede düşük saptandığı bir durumdur. Besinsel anemi en sık demir eksikliğine bağlı olmakla birlikte $\mathrm{B}_{12}$ vitamini, folat, çinko, bakır gibi vitamin ve minerallerin eksikliğine bağlı olabilir. Son 20 yılda demir eksikliği önemli bir halk sağlığ 1 sorunu haline gelmiştir. Dünya nüfusunun \%30’u, çoğunlukla demir eksikliğine bağlı olmakla beraber, anemiktir. Demir eksikliği; kanama ve paraziter infeksiyonlar sebebiyle de gelişebilir. Anemi gelişiminde sosyoekonomik faktörlerin de büyük payı vardır. ${ }^{3}$

Demirin, insan organizmasında yaygın olarak kullanılması nedeni ile eksiklik durumlarında tüm sistemler etkilenir ve pek çok sistemik belirti ve bulgu ortaya çıkabilir. ${ }^{1}$ Demir myelinizasyon ve dopamin, norepinefrin, serotonin gibi nörotransmitterlerin sentezinde gereklidir. ${ }^{4-6}$ Demir Eksikliği Anemisi (DEA) çocuk ve adolesanlarda bilişsel ve davranış testlerini olumsuz yönde etkilemektedir. ${ }^{7,9}$ Çocukluk çağında $\mathrm{B}_{12}$ vitamin eksikliği tanısı konulması, tedavi edilmesi önemlidir. Tedavi maliyeti düşük olmasına rağmen tedavide gecikme derin anemi, geri dönüşümsüz ciddi nörolojik hasar gibi ciddi komplikasyonlara neden olmaktadır. ${ }^{10}$

Adolesan yaş grubunda anemi en sık hızlı büyüme ve diyette yetersiz alım nedeni ile gelişmekte olup, beslenme ile ilişkili anemi toplumumuzda sık görülmektedir. Sosyoekonomik koşulların ülkemizde giderek daha kötüye gitmesi de kişinin yetersiz alımını derinleştirmektedir. ${ }^{1-3} \mathrm{Bu}$ yüzden böyle bir klinik çalışma yaparak adolesan yaş grubunda besinsel aneminin nedenlerini saptamayı amaçladık.

\section{MATERYAL VE METOT}

Nutrisyonel anemi tanısı almış hastaların verileri hastane ve bölüm dosyalarında retrospektif olarak değerlendirildi. Dokuz Eylül Üniversitesi Çocuk Sağlığı ve Hastalıkları Anabilim Dalı polikliniklerine 01.01.2014 - 01.07.2015 tarihleri arasında başvuran ve 10-18 yaşları arasında nutrisyonel anemi tanısı alan 90 çocuk incelenmiş olup, hastalara önceden hazırlanmış ve etik kurul onayı almış olan veri kayıt formu/ anket ( $\underline{\mathbf{E k} 1}$ ), tanı aldığı gün doldurtuldu. Çalışmaya, 10-18 yaş nutrisyonel anemi tespit edilmiş çocuklar ve büyüme gelişme geriliği, kronik malnütrisyon, enfeksiyon (viral, bakteriyel, paraziter vb.) tanılarından herhangi birine sahip çocuklar çocuklar dâhil edildi. Çalışmaya katılmak istemeyenler ve çalışmadaki anket sorularını algılayabilecek mental duruma sahip olmayan kişiler dâhil edilmedi. Araştırma için Dokuz Eylül Üniversitesi Girişimsel Olmayan Araştırmalar Etik Kurulu'ndan 26.12.2013 tarih ve 2013/47-18 karar no ile onay alınd.

Hasta bilgilerine hastane ve ilgili bilim dallarından alınan izinle arşiv dosyaları taranarak, yaş, cinsiyet, boy, ağırlık, boya göre ağırlık (W/H) ölçümleri hasta veri kayıt formlarına kaydedildi. Ayrıca olguların eğitim durumu, anne ve babalarının eğitim durumu, semptomları ve muayene bulguları, vejetaryenlik öyküleri, kırmızı et, sakatat, tavuk, balık, meyve, kuru baklagil, yumurta, yeşil yapraklı sebze gibi besinleri tüketim sıklığı sorgulandı. Anemi etiyolojisinde yer alan diğer sebepler (çay, kahve tüketimi, ekmek tüketimi, kronik hastalık, paraziter hastalık ve ilaç kullanım öyküsü) ve sosyoekonomik değerlendirme ile ilgili sorular da hasta ve hasta yakınlarına yöneltildi.

Veri çözümlemesinde, tanımlayıcı bulgular için sayımla belirtilen değişkenler sayı ve yüzdelerle, ölçümle belirlenen değişkenler, ortalama, ortanca, en düşük değer ve en yüksek değerle belirtilmiştir. Ölçümle belirtilen değişkenlerin dağılım özelliği Kolmogorov-Smirnov testi ile değerlendirilmiştir. Bağımsız değişkenlerin bağımlı değişkenle ilişkisini değerlendirmede sayımla belirtilen kategorik değişkenler için Ki-Kare testi ve Fisher'in kesin testi kullanılmıştır. Ölçümle belirtilen değişkenlerin bağımlı değişkenle ilişkisini değerlendirmede, Mann-Whitney U testi çözümlemesi kullanılmıştır. İstatistiksel anlamlılık düzeyi olarak $\mathrm{p}<0,05$ olarak kabul edilmiştir. Çözümlemede SPSS 15.0 istatistik paket programı kullanılmıştır.

\section{BULGULAR}

Çalışmaya katılan olguların yaş ortalaması $14,3 \pm 0,2$, medyan yaş 15 olarak saptand1. Olguların 87'sinde demir eksikliği anemisi, 3'ünde izole $\mathrm{B}_{12}$ vitamini eksikliğine bağlı anemi saptanmış olup, izole folat eksikliğine bağlı anemi tanısı alan olgu saptanmadi. Olguların \%76,7' si (69 olgu) kı, \% 23,3'ü (21 olgu) erkekti.

Demir eksikliği anemisi tanısı alan hastaların laboratuvar incelemesinde ortalama değer ve değer aralığı sırasıyla Tablo 1'de verilmiştir.

Demir eksikliği anemisi tanısı alan 27 olguda (\% 31) eş zamanlı B12 Vitamini eksikliği, 24 olguda (\% 27,5) folat eksikliği saptandı. Olguların \%67'si (58 
olgu) izole demir eksikliği anemisi tanısı almış olup, \%33'ünde (29 olguda) eş zamanlı $\mathrm{B}_{12}$ vitamini eksikliği ve/veya folat eksikliği saptandı. DEA tanısı alan 5 olguda (\%6) eş zamanlı $\mathrm{B}_{12}$ vitamini eksikliği ve folat eksikliği saptandı. 15 olguda (\% 16,7) hemoglobin değeri, $9 \mathrm{gr} / \mathrm{dL}$ ve altında olup; 75 olguda $(\% 83,3) 9 \mathrm{gr} / \mathrm{dL}$ nin üstünde saptand.

$\mathrm{B}_{12}$ eksikliği anemisi tanısı alan 3 olgunun laboratuvar incelenmesinde ortalama değer ve değer aralığı sırasıyla Tablo 2'de verilmiştir.

Kırmızı et yeme sıklığının değerlendirilmesinde, bireylerin \%24,4'ü hiç kırmızı et tüketmezken, \% 38'inin ayda bir kez, \%28,9'unun haftada bir kez, $\% 8,9$ 'unun gün aşırı et tükettiği görüldü. Kızların \%37'si (26) ayda bir, \%26's1 (18) haftada bir, \%5,7 si (4) gün aşırı, \%1,4 ü (1) her gün tükettiğini \% 28,9'u (20) hiç tüketmediğini; erkeklerin \%38'i (8) ayda bir, \%38'i (8) haftada bir, \%14,5'u (3) gün aşırı tüketirken, \%9,5'u (2) hiç tüketmediğini belirtti. Kırmızı et yeme sıklığının hemoglobin, ferritin ve transferrin değerleri arasında t-testi ile yapılan istatistiksel analizde anlamlı ilişki saptanmadı $(p=0,3)$. Kırmızı et yeme sıklığı ile B12 vitamini düzeyi arasında ki-kare testi ile yapılan analizde de anlamlı fark saptanmadi $(\mathrm{p}=0,2)$.

Tavuk eti yemek sıklığının değerlendirilmesinde, olguların \%25,6'sı hiç tavuk eti tüketmezken, \% 54,4'ü haftada bir, \%11,1'i gün aşırı, \%1,1'i her gün tavuk eti tükettiği saptandı. Tavuk eti yeme sıklığının hemoglobin, ferritin, transferrin arasında $t$ -testi ile yapılan istatiksel analizde; tavuk eti yeme sıklığı ile transferrin saturasyonu arasında anlamlı ilişki saptandı $(\mathrm{p}=0,03)$.

Hastalara ekonomik iyilik hali sorulduğunda, hastaların \%5'inin kötü, \%70'inin orta , \%21' inin iyi, \% 4'ünün kendini ekonomik olarak çok iyi hissettiği öğrenildi. Ekonomik iyilik hali daha iyi olan ailelerin çocuklarında, diğer çocuklara göre anemi derinliği açısından MannWhitney U testi ile yapılan analizde istatistiksel anlamlılık saptandı $(\mathrm{p}=0,004)$. Olguların aylık ortalama geliri sorgulandığında; \% 52,2'sinin 1501 lira ve üstü, \%34,4'ünün 10011500 lira, \%11,1'inin 500-1000 lira, \%2,2'sinin 500 lira altı aylık gelirinin olduğu saptandı. Aylık ortalama gelir ile hemoglobin, transferin saturasyonu ve ferritin düzeyleri arasında MannWhitney U testi ile yapılan analizde anlamlı ilişki saptanmadı $(p=0,5)$.

\section{TARTIŞMA VE SONUÇ}

Adolesan döneminde hızlı büyüme nedeniyle demir ve diğer besin öğelerine olan ihtiyaç artmaktadır. Kız çocuklarının adet görmeye başlaması da demir eksikliği ve demir eksikliği anemisinin ortaya çıkmasına katkıda bulunmaktadır. Ek olarak adolesanlarda görülebilen düzensiz yemek yeme alışkanlıkları da nutrisyonel anemiye yol açabilmektedir. Çalışmamızda yer alan nutrisyonel anemili adolesan olgularda en sık demir eksikliği anemisi saptanmıştır ve bu olguların büyük bir kısmını kı çocukları oluşturmuştur. Ülkemizde ve dünyada adolesanlarda anemi prevalansını ve etiyolojisini saptamaya yönelik sınırlı sayıda çalışmalar yapılmıştır. Batı Karadeniz bölgesinde adolesanlarda anemi prevalansı $\% 5,9$, demir eksikliği prevalansı $\% 2,2$, Sivas'ta 12-18 yaş grubu adolesanlarda DEA prevalans1 k1zlarda $\% 6,7$ erkeklerde $\% 4,2$, İzmir' de adolesan okul çocuklarında DEA \%6,7, Denizli'de adolesan çocuklarda DEA prevalansı \%41, kombine şekilde demir eksikliği ve $\mathrm{B}_{12}$ vitamini eksikliği anemisi prevalansı \%59 saptanmıştır. Irak'ta adolesan çocuklarda anemi sıklığı kırsalda \%12,9 kentsel nüfusta \%17,6 bulunmuştur. İran'da 14-20 yaş arası adolesan grupta anemi sıklığı \% 21,4; Filistin'de 13-15 yaş arası grupta erkeklerde \%6-22,5, kızlarda \%9,2-9,3; Mısır'da 12-18 yaş arası grupta $\% 46,6$ saptanmıştır. ${ }^{11-18}$

Adolesan anemisine yönelik Türkiye'de yapılmış olan çalışmalarda kızlarda anemi prevalansının yüksek saptanması kızların adet görmesi ve hayvansal gıdalardan fakir, meyve sebze ağırlıklı (Akdeniz diyeti) ve düzensiz beslenmeleri ile ilişkilendirilmiştir. ${ }^{11-13}$

Çalışmamızdaki nutrisyonel anemili olguların \% 33'ünde demir eksikliği ile birlikte kombine $\mathrm{B}_{12}$ vitamini ve/veya folik asit eksikliği saptanmıştır. Olgularımızın beslenme öyküsünde yaklaşık dörtte birinde haftada bir veya daha az yumurta tüketimi varken, süt ürünleri, meyve tüketimi daha fazlaydı. Denizli'de Balcı ve arkadaşlarının yaptığı çalışmada da demir eksikliği anemisine $\% 41$ oranında $\mathrm{B}_{12}$ vitamini eksikliğinin de eşlik ettiği görülmüştür. ${ }^{14}$ Olgularımızda izole $\mathrm{B}_{12}$ vitamini eksikliğine bağlı megaloblastik anemi \%3,3 oranında bulunmuş, izole folik asit eksikliği saptanmamıştır. Ancak \% 27,5 oranında demir eksikliği anemisi ile birlikte kombine folik asit eksikliğinin de olduğu görülmüştür. Öncel ve arkadaşlarının Diyarbakır'da 12-22 yaş arasında toplam 889 olguda yaptıkları çalışmada $\mathrm{B}_{12}$ vitamin ve folik asit eksikliği sırasıyla \%2,2 ve $\% 21,8$ oranında bildirilmiştir. ${ }^{18}$ Christel ve arka- 
daşları yaptıkları çalışmada vejetaryen çocuklarda $\mathrm{B}_{12}$ vitamini düşüklüğü saptamış ve beslenmenin önemine değinmişlerdir. ${ }^{19}$ Vanderjagt ve arkadaşlar1, adolesan kılarda $B_{12}$ vitamini eksikliği prevalansını yüksek bulmuşlar ve bunu diyetle yetersiz alıma bağlamışlardır. ${ }^{20}$ Osifo ve arkadaşları ise ortalama $\mathrm{B}_{12}$ vitamini ve folat düzeylerini kılarda daha yüksek bulmuşlar, bunu da özellikle kızlarda 10-14 yaş grubunda puberteden dolayı metabolik ihtiyacın artmasına bağlı olarak depolardan plazmaya daha fazla folat transferine bağlamışlardır. ${ }^{21}$ Cunnigham ve arkadaşları ise Kosta rika'da yaptıkları çalışmada folat eksikliğini $(<6 \mathrm{ng} / \mathrm{ml}) \%$ 11,4 saptamışlar ve araştırmada bunun nedeninin nutrisyonel olduğunu rapor etmişlerdir. ${ }^{22}$ Wetherilt ve ark.'ları Türkiye'de 7-17 yaş grubunda 960 çocukta yaptıkları çalışmada folat eksikliğini $\% 23,3$, $\mathrm{B}_{12}$ vitamini eksikliğini \%5,9 oranında saptamışlardır. ${ }^{23}$ Öner ve arkadaşları ise Edirne'de 12-17 yaş grubunda 704 kızda folik asit eksikliğini \%16,3 oranında saptamışlar ve bunu diyetle folat alımının yetersizliği ile ilişkilendirmişlerdir. ${ }^{24}$

Çalışmamızda kırmızı et tüketimi ile hemoglobin, ferritin, transferin değerleri arasında istatistiksel olarak anlamlı ilişki saptanmazken; tavuk eti tüketimi ile transferin saturasyonu arasında anlamlı ilişki saptanmıştır. Toplumumuz, sosyoekonomik vb. nedenlerden dolayı kırmızı eti kısıtlı tüketmektedir. $^{25}$ Temel et tüketimi, tavuk etine kaydığı için tavuk eti ile anlamlı ilişki olduğu düşünülmüştür.

Çalışmamızda aylık ortalama gelir ile hemoglobin, transferin saturasyonu ve ferritin düzeyleri arasında Mann Whitney U testi ile yapılan analizde anlamlı ilişki saptanmadı. Seçilen örneklemin benzer sosyoekonomik koşullara sahip kişiler olması nedeniyle, istatiksel analizin anlamlı olmadığı düşünüldü. Ekonomik iyilik hali daha iyi olan ailelerin çocuklarında, diğer çocuklara göre anemi derinliği açısından Mann Whitney U testi ile yapılan analizde istatistiksel anlamlılık saptandı $(p=0,004)$. Ekonomik iyilik hali öznel bir değerlendirme olarak düşünülmelidir. Toplumun sosyoekonomik koşullarını birebir yansitmamaktadir.

Sonuç olarak adolesanlarda büyüme nedeniyle artan ihtiyaç, sosyoekonomik faktörler, uygun olmayan beslenme alışkanlıkları ve yanlış diyetler nedeniyle başta demir eksikliği anemisi olmak üzere nutrisyonel anemiler görülebilmektedir. Adolesanların izlemde mutlaka nutrisyonel anemi riski açısından değerlendirilmesi gerektiği ve koru- yucu hekimlik uygulamalarına da yer verilmesi gerektiği düşünülmüştür.

Etik Komite Onayı: Çalışmamız Dokuz Eylül Üniversitesi Girişimsel Olmayan Araştırmalar Etik Kurulu (karar no: 2013/47-18) tarafindan onaylandi.

Çıkar Çatışması: Yazarlar çıkar çatışması bildirmemişlerdir.

Yazar Katkuları: Fikir - E.G. ; Denetleme - E.G.; Malzemeler - E.G.; Veri toplanması ve/veya işlemesi-E.G.; Analiz ve/veya yorum - E.G. ; Yazıyı yazan - E.G.

Hakem değerlendirmesi: Dış bağımsız.

Teşekkür: Yazar, yazının redaksiyon işlemine katkı sağlayan Prof. Dr. Gülarsu İrken'e teşekkür eder.

Ethics Committee Approval: Our study was approved by the Dokuz Eylül University NonInvasive Research Ethics Committee (decision no: 2013/47-18).

Conflict of Interest: No conflict of interest was declared by the authors.

Author Contributions: Concept - E.G.; Supervision - E.G.; Materials - E.G.; Data Collection and/or Processing -E.G.; Analysis and/ or Interpretation E.G. Writing - E.G.

Peer-review: Externally peer-reviewed.

Acknowledgement: The author thank to Prof. Dr. Gülarsu İrken.

\section{KAYNAKLAR}

1. Gedikoğlu G, Ağaoğlu L. Kan Hastalıkları In: Neyzi O, Ertuğrul T; Pediyatri, Cilt 2, 4. Edisyon; Nobel Tıp Kitabevleri 2010.

2. Lanzkowsky P. Manual of Pediatric Hematology and Oncology; Fifth Edition, 2011.

3. WHO/UNICEF Iron Deficiency Anemia, Assesment, Prevention, Control; a Guide For Programme Managers; WHO 2001.

4. Beard JL, Connor JR. Iron status and neural functioning. Annu Rev Nutr. 2003; 41-58.

5. Black MM. Micronutrient deficiencies and cognitive functioning. J Nutr. 2003;133 (suppl):3927S-3913S.

6. Grantham-Mcgregor S, Ani C. A review studies on the effect of iron deficiency on cognitive development in children. J Nutr. 2001;131 (suppl):694S-666S; discussion 666S-668S.

7. Connor JR, Menzies SL. Relationship of iron iron to oligodendrocytes and myelination. Glia. 
1996;17:83-93.

8. Ortiz E, Pasquini JM, Thompson K, et al. Effect of manipulation of iron storage, transport or availability on myelin composition and brain iron content in three different animal models. J Neurosci Res. 2004;77:681-689.

9. Youdim MB, Yehuda S. The neurochemical basis of cognitive deficits induced by brain iron deficiency: involvement of dopamine-opiat system. Cell Mol Biol. 2000;46:491-500.

10. Brocadello F, Levedianos G, Piccione F, Manara R, Pesenti FF. Irreversible subacute sclerotic combined degeneration of the spinal cord in a vegan subject. Nutrition. 2007;23;622624.

11. Yavuz T, Korkut S, Yavuz O, Kocabay K. Batı Karadeniz Bölgesinde Adolesanlarda anemi ve Demir Eksikliği Anemisi Prevalansı. Türkiye Klinikleri Pediatri Dergisi. 2004;13:71-75.

12. Berçem İ, İçağasıoglu D, Cevit Ö, et al. Sivas'ta 12-18 yaş grubu adolesanlarda demir eksikliği ve demir eksikliği anemisi prevalansı. Türkiye Klinikleri Pediatri Dergisi. 1999;8:15-20.

13. Aydınok Y, Öztop S, Nişli G, Kavaklı K, Çetingül N. Percentile Norms and Curves for hematological values in Turkish adolescents. Turkish Journal of Hematology. 1998;15:169173.

14. Balcı Y, Karabulut A, Gürses D, Çövüt İ. Prevalance and Risk Factors Of Anemia among Adolescents in Denizli, Turkey. Iran J Pediatr. 2011;2 22:77-81.

15. Al-Sharbati SS, Al-Ward NJ, Al-Timini DJ. Anemia among adolescents. Saudi Med j. 2003;24: 189-94.

16. Akramipour R, Rezaei M, Rahimi Z. Prevalance of iron Deficiency anemia among adolescents school girls from Kermanshah, Western Iran. Hematology.2008;13(6):352-5.

17. Mikki N, Abdul-Rahim HF, Stigum H, et al. Anemia Prevalance and associated sociodemoraphic and dietary factors among palestinian adolescents in the West Bank. East Mediterr Health J. 2011;17(3):208-17.

18. Öncel K, Özbek M, Onur H, Söker M, Ceylan A, Diyarbakır İlindeki Çocuklarda ve adolesanlarda ${ }_{\mathrm{B} 12}$ vitamin ve folik asit düzeyleri. Dicle Tıp Dergisi. 2006;33-3:163-169.

19. Christel LL, Gunnar KJ. Dietary intake and nutritional status of young vegans and omnivores in Sweden. Am J Clin Nutri 2002;76 (1):100-6.

20. Vanderjagt DJ, Spelman K, Ambe J, et al. Folate and Vitamin B12 status of adolescent girls in Northern Nigeria. J Natl Med Assoc 2000;92 (7):334-340.

21. Osifo BO, Lukanmbi FA, Bolodeoku JO. Reference values for serum folate, erythrocyte folate and serum cobalamin in Nigerian adolescents. Trop Geogr Med. 1986;38:259264.

22. Cunningham L, Blanco A, Rodriguez S, Ascencio M. Prevalance of anemia, iron and folate deficiency in children 7 years smaller. Costa Rica, 1996 Arch Latinoam Nutr. 2001;51:37-43.

23. Welherilt H, Ackurt F, Brubacher G. Blood vitamin and mineral levels in 7-17 years old Turkish children. Int $\mathrm{J}$ Vitam Nutr Res. 1992;62:21-29.

24. Öner N, Aladağ N, Vatansever Ü. et al. Edirne İlinde Yaşayan Adolesan Kızlarda Folik Asit Prevalansının Araştırılması. VI. Ulusal Çocuk Gastroenteroloji, Hepatoloji ve Beslenme Kongresi 2004. Poster No: 105. Kongre Kitab1 169.

25. Türkiye Beslenme ve Sağlık Araştırması 2010, Beslenme durumu ve sağlık alışkanlıkları değerlendirilmesi sonuç raporu; 2014. 
Tablo1. Demir eksikliği anemisi tanısı alan hastaların laboratuar sonuçları.

\begin{tabular}{|l|l|}
\hline Değişken & $\begin{array}{l}\text { Ortalama } \pm \text { Standart sapma } \\
\text { (Ortalama Değer Aralığı) }\end{array}$ \\
\hline Eritrosit Sayısı (milyon) & $4,45 \pm 0,72(2,10-6,63)$ \\
\hline Hemoglobin $(\mathrm{g} / \mathrm{dL})$ & $10,4 \pm 0,2(4,8-12,9)$ \\
\hline Hematokrit $(\%)$ & $32,2 \pm 0,55(16-40)$ \\
\hline OEH(fL) & $72,5 \pm 1,1(49,4-89)$ \\
\hline RDW (\%) & $17,5 \pm 0,4(12,3-32,8)$ \\
\hline Ferritin $(\mathrm{ng} / \mathrm{ml})$ & $9,6 \pm 1,4(1-88)$ \\
\hline Demir $(\mu \mathrm{g} / \mathrm{dL})$ & $30,8 \pm 0,6(5-134)$ \\
\hline Demir bağlama kapasitesi $(\mu \mathrm{g} / \mathrm{dL})$ & $381,6 \pm 7,7(145-550)$ \\
\hline Transferrin saturasyonu $(\%)$ & $7,9 \pm 0,73(1,4-40)$ \\
\hline$B_{12}$ Vitamini (pg/ml) & $289 \pm 31(25-1471)$ \\
\hline Folat (ng/mL) & $9,7 \pm 0,8(3,1-24,6)$ \\
\hline
\end{tabular}

OEH: Ortalama Eritrosit Hemoglobini. $\underline{R D W}$ : Red Cell Distribution Width( Eritrosit Dağıllım Genişliği) 
Tablo 2. $\mathrm{B}_{12}$ vitamini eksikliğine bağlı anemisi olan hastaların laboratuar sonuçları.

\begin{tabular}{|l|l|}
\hline Değişken & $\begin{array}{l}\text { Ortalama } \pm \text { Standart sapma } \\
\text { (Ortalama Değer Aralığı) }\end{array}$ \\
\hline Eritrosit Sayısı (milyon) & $2,97 \pm 0,2(2,1-3,5)$ \\
\hline Hemoglobin (g/dL) & $8,6 \pm 0,3(7,4-10,9)$ \\
\hline Hematokrit (\%) & $25 \pm 0,3(21-30)$ \\
\hline OEH(fL) & $100 \pm 0,3(100-103)$ \\
\hline RDW(\%) & $18,5 \pm 0,03(15,8-22,5)$ \\
\hline $\mathrm{B}_{12}$ vitamini $(\mathrm{pg} / \mathrm{mL})$ & $50 \pm 0,3(25-76)$ \\
\hline
\end{tabular}

OEH: Ortalama Eritrosit Hemoglobini . RDW: Red Cell Distribution Width( Eritrosit Dağılım Genişliği) 
Ek1. Veri Kayıt Formu Örneği/Anket Formu.

1. Vejetaryen (Sebze ve meyve ağrllkkh beslenen, et yemeyen) misiniz?

A) Evet B) Hayir

2. Ill soruya cevabiniz evet ise, ne zamandir vejeteryansiniz?

3. Ailenizde ( anne ,baba, kardes $\mathrm{vb}$ ) vejeteryan beslenen kimse var m?

A) Evet(.........................) B) Hayr

4. Kırmız Et ( dana, koyun, kuzu, keçi, oğlak vb ) yeme sıklığınız nedir? A) Ayda 1 kez B) Haftada 1 kez C) Gün aşın D) Her gün E) Hiç

5. Eti nasil yemeği tercih edersiniz?

A)Köfte şeklinde B) parça et olarak C) kanşık kyyma şeklinde D) Sucuk, Salam, Sosis vb. E) diğer(

6. Hindi eti yeme sıkliğınız nedir?

A)Ayda 1 kez B) Haftada 1 kez C) Gün aşın D) Her gün E) Hiç

7. Tavuk eti yeme siklığınız nedir?

A)Ayda 1 kez B) Haftada 1 kez C) Gün aşın D) Her gün E) Hiç

S. Sakatat ürünleri(karaciğer, böbrek vb.) yeme sikliğınız nedir?

A)Ayda 1 kez B) Haftada 1 kez C) Gün aşin D) Her gün E) Hiç

9. Balik yeme sikhğınız nedir?

A)Ayda 1 kez B) Haftada 1 kez C) Gün aşın D) Her gün E) Hiç

10. Somon ve ton baliğı yeme siklğınız nedir?

A)Ayda 1 kez B) Haftada 1 kez C) Gün aşın D) Her gün E) Hiç

11. Kabuklu deniz ürünleri(Midye, istridye) yeme sıklığınz nedir? A)Ayda 1 kez B) Haftada 1 kez C) Gün aşın D) Her gün E) Hiç

12. Yumurta( pişmiş) yeme sıklı̆ğıız ne dir? (Günde 1 den fazla yiyen varsa not ediniz)

A)Ayda 1 kez B) Haftada 1 kez C) Gün aşın D) Her gün E) Hiç

13. Taze Meyve (elma, üzüm, erik, kayısı, dut, portakal, kavun, çilek, muz )yeme sıkłı̆ınız nedir? A)Ayda 1 kez B) Haftada 1 kez C) Gün aşin D) Her gün E) Hiç

14. Kuru meyve (Kuru üzüm, kuru kayısi, dut, erik, vişne, kurutulmuş meyvelerden yapılan pestil, cevizli pestil,pekmez vb ) yeme siklğınız nedir?

A)Ayda 1 kez B) Haftada 1 kez C) Gün aşın D) Her gün E) Hiç

15. Kuru baklagiller (Nohut, Fasülye, Mercimek, Börülce, Bakla, Bezelye) yeme sıklı̆ınız nedir? A)Ayda 1 kez B) Haftada 1 kez C) Gün aşın D) Her gün E) Hiç

16. Koyu yeşil yaprakkh sebze(1spanak, pazı, roka, tere vb) yeme siklığnız ne dir?

A)Ayda 1 kez B) Haftada 1 kez C) Gün aşın D) Her gün E) Hiç

17. Kuru yemişleri ( ceviz, badem, findık, yer fistığı vb) tüketiyormusunuz, sıklığı nedir?

A)Ayda 1 kez B) Haftada 1 kez C) Gün aşin D) Her gün E) Hiç

18. Günde ortalama ne kadar ekmek tüketiyorsunuz?

19. S1kllkla tercih ettiğiniz elkmek tipi hangisidir ?

A)Kepekli Ekmek B) Tam buğday ekmeği C) Beyaz ekmek D) Çavdar ekmeği E) diğer(

20. Yemeklerden yanm saat önce veya sonra çay içer misiniz? A)Evet B) Hayır

21. Günde ortalama kaç bardak çay içersiniz? 22. Günde ortalama kaç fincan kahve tüketirsiniz? .......

23. Demir ve vitamin ile zenginleştirilmiş mısır gevreği veya tahıl gevrekleri tüketir misiniz ?

A) Evet B) Hayir

24. Vitamin ve mineral haplan alir misiniz?Ne siklikla alirsinız? İsimleri nedir? .

25. Toprak, kum, boya gibi maddeleri yeme alışkanlığınız var midır?

26. Dişkanızda barsak paraziti gördünüz mü veya laboratuar incelemelerinde size dışkanızda barsak paraziti olduğu söylendi mi?

27. Tedavi olduğunuz veya takip edildiğiniz bir hastalığınız var mı? Varsa isim $/$ isimleri nedir? ...

28. Uzun süre dir kullandığınız ilaçlar var mı?

A)Evet B) Hayri

29. Kullandığınız ilaç varsa isim/ isimleri nedir?

30. Size hiç kan verildi mi?

A)Evet B) Hayr

Kızlar için(31-32. Sorular):

31. Illk kez kaç yaşında adet gördünüz? ....

32. Adet kanamanız ortalama kaç gün sürüyor?.....

33. Ailenizin ortalama aylk gelin nedir?

A) 500 liradan az B) 500 lira C) $501-1000$ lira D) 1001-1500 lira E) 1500 liradan fazla

34. Kendinizi ekonomik yönden nasil hissediyorsunuz?

A) Çok Iyi B) Iyi C) Orta D) Kötü E) Çok Kötü

35. Eviniz kendinize mi ait, yoksa kirada mi oturuyorsunuz? .......

36. Evinizde kaç oda bulunuyor ve aynı evde kaç kişi yaşıyorsunuz? .... 